\title{
Algılanan Örgütsel Politikanın Ardılları Üzerine Ulusal Yazın Bağlamında Bir Meta-Analiz Çalışması ${ }^{1}$
}

\begin{abstract}
Öz
Bu çalışmanın amacı, örgütsel politika algılarını (AÖP), Türkiye'de yapılan akademik çalışmalar üzerinden sistematik bir biçimde değerlendirmektir. Bu bağlamda, örgütsel politika algılarının ardıllarının tespit edilmesi ve ulusal yazın kapsamında, örgütsel politika algılarının çeşitli birey/örgüt düzeyi değişkenlerle nasıl ilişkilendiğinin belirlenmesi amaçlanmaktadır. Bu doğrultuda, Ulakbim TR Dizin, YÖK Ulusal Tez Merkezi, Academic Search Complete, Business Source Complete, Emerald Insight, ERIC, DOAJ, IEEE XploreDigital Library, JSTOR, PsycINFO, Sage Journals Online, Science Direct, Springer Link, Taylor and Francis Online Journals, Wiley Online Library, Clarivate Analytics (Web of Science) veri tabanlarında yer alan dergiler ile Ulusal Yönetim ve Organizasyon Kongresi, İşletmecilik Kongresi ve Örgütsel Davranış Kongresi bildiri kitaplarında belirlenen anahtar sözcükleri içeren bildiriler, makaleler ve tezler taranmıştır. 18 farklı çalışmadan edinilen 33 bireysel veri üzerinden CMA yazılımı ile gerçekleştirilen analizler neticesinde, algılanan örgütsel politikanın ihmalkârlık, işten ayrılma niyeti ve tükenmişlik ile pozitif yönde ve zayıf-orta düzeylerde ilişkili olduğu; özdeşleşme, iş tatmini ve bağlılık ile negatif yönde ve orta düzeylerde ilişkili olduğu tespit edilmiştir.
\end{abstract}

Anahtar Kelimeler: Algılanan Örgütsel Politika, Ulusal Örgütsel Davranış Yazını, Meta-analiz
Deniz Dirik ${ }^{2}$

Hakkı Okan Yeloğlu³

A Meta-Analysis of the Outcomes of Perceived Organizational Politics in the Context of Turkish Organizational Behavior Literature

\section{Abstract}

The purpose of this study is to make a systematic analysis of the studies on perceived organizational politics (POPs) in Turkish organizational behavior literature. In this context, the study attempts to identify the individual/organizational level outcomes of POPs as well as to explore the direction and strength of variable-level correlations. To that end, we searched for papers and articles including the designated keywords in the National Academic Network and Information Center, The Council of Higher Education Thesis Center, Academic Search Complete, Business Source Complete, Emerald Insight, ERIC, DOAJ, IEEE XploreDigital Library, JSTOR, PsycINFO, Sage Journals Online, Science Direct, Springer Link, Taylor and Francis Online Journals, Wiley Online Library, Clarivate Analytics (Web of Science) and the Books of Proceedings of the National Congress on Management and Organization, Business Congress and the Congress on Organizational Behavior. We conducted the meta-analysis on a sample of 18 different studies involving 33 unique data sets using Comprehensive Meta-Analysis software. According to our findings, perceived organizational politics is positively correlated with negligence, intention to leave, and burnout at small-to-moderate effect sizes, and is negatively correlated with identification, job satisfaction and commitment at a moderate level.

Keywords: Perceived Organizational Politics, National Organizational Behavior Literature, Meta-analysis

\section{Giriş}

Politika, toplumsal ve örgütsel hayatın kaçınılmaz bir parçasıdır. Örgütsel davranış alanında "Politika nedir?" sorusunun cevabı farklı yazarlar tarafından sürekli olarak aranmıştır. Örgütsel politika, iki farklı bakış açısıyla, kimi zaman örgütlerin karanlık yüzü, kimi zaman ise arzulanan sonuçlara ulaşmayı sağlayan bir araç olarak değerlendirilmiştir (Yüksel, 2013). Politik davranışlar, yoğunlukla "karanlık" tarafına vurgu yapılan, kişinin kendi çıkarını maksimize etme çabasıyla ilişkilendirilen, örgütün etkililiğine zarar veren ve iş çevresini olumsuz etkileyen davranış-

\footnotetext{
${ }^{1}$ Bu çalışmanın öncü bir versiyonu, 2-3 Kasım 2018 tarihinde Isparta Süleyman Demirel Üniversitesi tarafından düzenlenen 6. Örgütsel Davranış Kongresinde sözel bildiri olarak sunulmuştur.

2 Doç. Dr., Manisa Celal Bayar Üniversitesi IiBF, İşletme Bölümü. deniz.ispirli@cbu.edu.tr, Yazar ORCID bilgisi: https://orcid.org/0000-0002-7652-5079

${ }^{3}$ Prof. Dr., Başkent Üniversitesi iiBF, Teknoloji ve Bilgi Yönetimi Bölümü. okany@baskent.edu.tr, Yazar ORCID bilgisi: https://orcid.org/0000-0001-9424-3094
} 
lar olarak tanımlanmaktadır (Atınç vd., 2010; Ferris ve King, 1991). Her ne kadar politik davranışlar olumludan olumsuza geniş bir yelpazede sonuçlar doğursa da insanların, nesnel gerçeklikten ziyade algılar üzerinden davranışlarını yönlendirdikleri (Ferris vd., 1989) önermesi uyarınca, politik davranışların kendisinden öte nasıl algılandığı akademik araştırmaların odağını oluşturmuştur (Ferris vd., 2002). Politika kavramının müphem olduğu ölçüde içeriksel olarak kapsamlı bir kavram olan örgütsel politika, söylenen sözler ve sergilenen davranışlar kadar söylenmeyen sözler ve sergilenmeyen davranışları dahi kapsadığından, karmaşık ve çetrefillidir (Mohan-Bursalı, 2008). Nitekim örgütsel kararlar, dağıtılan kaynaklar, terfi, maaş, yönetici ve akranlar hakkında sarf edilen sözler ile örgüt içerisinde alınan kararları, kaynakların paylaşımını, terfi süreçlerini ve iş arkadaşlarını etkileme amaçlı her türlü eylem, politikanın sınırlarına dâhildir. Yine, bir durum karşısında çeşitli gerekçelerle sessiz ve eylemsiz kalmak da bir o kadar politik bir davranış olabilmektedir (Mohan-Bursalı, 2008). Birey veya kliklerin, örgütsel (kıt) kaynakların dağıtımı için rekabet ederken stratejiler ve amaçlar ürettikleri süreç (Ertekin ve Yurtsever Ertekin, 2003:2) şeklinde tanımlanan örgütsel politika, genellikle kişisel çıkarları korumak ve geliştirmek üzere sergilenen davranışlar olarak yorumlanmaktadır (Ferris ve Kacmar, 1992).

Mayes ve Allen (1977:675'ten aktaran Mohan-Bursalı, 2008), örgütsel politikayı, “örgüt tarafından onaylanmayan sonuçları elde etmek veya örgüt tarafından onaylanan sonuçları örgütçe onaylanmayan araçlarla elde etmek için etkileme sürecinin yönetilmesi" şeklinde tanımlamaktadır. Pfeffer'a (1981: 7) göre örgütsel politika, seçimlere ilişkin belirsizlik veya anlaşmazlık olduğu durumlarda, kişisel amaçları gerçekleştirmek üzere gücü ve kaynakları ele geçirmek için kalkışılacak her türlü eylem olarak tanımlanmaktadır. Porter, Allen ve Angle (1981: 359) örgütsel politikayı, kişilerin ve grupların çıkarlarını korumaya yönelik, ihtiyari ve diğerlerinin çıkarlarına tehdit oluşturan sosyal etkileme girişimleri olarak nitelemektedir. Tanımların ortak noktası ise örgütsel politikanın olumsuzluğudur. Nitekim Gandz ve Murray (1980) çalışmasına göre yöneticilerin \%93'ü örgütsel politikanın varlığını olağan görmekte; \%89'u başarılı yöneticilerin iyi politikacılar olması gerektiğini düşünmekte ve \%70'i politik davranmanın örgütlerde ilerlemek için gerekli olduğunu savunmaktadır. Yine bu yöneticilerin \%55'i politikanın verimliliğe zarar verdiğini, \%48'i de tepe yönetimin politikayı örgütten uzaklaştırması gerektiğini düşünmektedir. Buna göre, politika, örgütler ve bireyler için gerekli ancak bir o kadar da hoşlanılmayan bir kavramdır.

Olumlu sonuçlara ulaşmak veya olumsuz sonuçlardan kaçınmak adına uygulanan kişiler arası bir etki olarak tanımlanan ve olumsuz yönüne vurgu yapılan politika, örgütsel alanda istenmeyen birtakım iş çıktıları ile ilişkilendirilmiştir. Örgütsel politika algılarının sonuçları üzerine uluslararası yazında yapılan bir meta-analiz çalışmasında (Miller vd., 2008) iş tatmini ve örgütsel bağıılığın olumsuz ilişkilenen sonuçları teşkil ettiği ve iş stresi ile işten ayrılma niyetinin olumlu etkileşen çıktılar olduğu tespit edilmiştir. Çalışanların örgüt ortamını politik olarak algılamaları, adalet ve güven duygularını sarsabilmekte; işten ayrılma niyeti, düşük performans, azalan vatandaşlık ve iş doyumu, azalan bağlılık ve artan iş stresi, iş kaygısı, psikolojik gerilim gibi sonuçlar doğurabilmektedir (Chang vd., 2009; Eryılmaz ve Altın-Gülova, 2017; Ferris vd., 1989). Aksine örgütsel bağlılık, örgütsel destek, örgütsel adalet gibi çeşitli değişkenler ise bireylerin politikaya yönelik olumsuz algılarını azaltabilmekte ve örgütsel sonuçları olumlu yönde etkileyebilmektedir.

Olası negatif sonuçlara ilişkin güçlü bulgular veri iken, örgütsel politik algılardan ileri gelen faktörlerin tespit edilmesi, örgütler için önem arz etmektedir. Ancak, bireysel ampirik araştır- 
malardan elde edilen tekil verilerin oy sayma (vote counting) yöntemiyle değerlendirilmesi şeklinde karşımıza çıkan bu türden değerlendirmeler (Ferris vd., 2002) algılanan örgütsel politikanın ilişkili olduğu değişkenleri tespitte ve bu değişkenlerle ilişkisinin yönünü ve gücünü yordamada yetersiz kalabilmektedir (Atınç vd., 2010). Tüm bu ilişkili değişkenler arasında hangisinin algılanan örgütsel politikanın en önemli sonucu olduğu ise yine tekil araştırmalarla yanıtlanamayacak bir sorunsal olarak durmaktadır. İşte meta-analiz, algılanan örgütsel politika konusuna ilişkin biriken alanyazının sistematik biçimde incelenerek bulguların süzülmesini ve istatistiki olarak anlamlı/güçlü çıkarımlar ve genellemeler yapılmasını sağlayacak bir yöntem olarak, sözü edilen eksikliği giderebilecek bir çerçeve sunmaktadır.

Özellikle ulusal yazına konu olan çalışmalar arasında, algılanan örgütsel politika konusunda önde gelen çalışmalara imza atan Ferris ve arkadaşlarının (2002) bütüncül modelinde işaret edildiği şekilde kapsamlı ampirik araştırmalar bulunmamaktadır. Dahası, bu modelin ulusal bağlamda geçerliliğini sorgulayan herhangi bir kuramsal tartışmaya, kavramın ampirik olarak ölçümüne yönelik bir ölçek geliştirme çalışmasına veya algılanan örgütsel politikaya dair çaıışmalar üzerinden ulusal bağlamda gerçekleştirilen bir meta-analiz çalışmasına rastlanmamıştır. Bu durum, algılanan örgütsel politikaya ilişkin akademik çabaların bütünleştirilmesi ve genel bir çerçeve çizilmesi ihtiyacını gündeme getirmektedir. Nitekim Hunter ve Schmidt (2004) bilimsel bir sorunu ele almada tekil çalışmaların kaçınılmaz biçimde yetersiz kaldığını, ancak ve ancak bu türden çalışmaların bir araya getirilmesiyle anlamlı bilgilere ulaşılabileceğini önermektedir. Bu bağlamda, bu çalışmanın amacı, örgütsel atmosfere ilişkin çalışan görüşlerinin bir yansıması olan örgütsel politika algılarını, Türkiye'de yapılan akademik çalışmalar üzerinden sistematik bir biçimde değerlendirmek ve gözden geçirmek şeklinde belirlenmiştir. Örgütsel politika algılarının ardıllarının tespit edilmesi ve ulusal yazın kapsamında, örgütsel politika algılarının çeşitli birey/örgüt düzeyi değişkenlerle nasıl/ne düzeylerde ilişkilendiğinin belirlenmesi çalışmanın başlıca amacıdır. Bu şekilde, algılanan örgütsel politikanın kuramsal ve pratik doğurgularının tespit edilmesi, uygulamacılar açısından politika algılarının zararlı etkilerinin azaltılması yolunda atılabilecek adımların tespitini sağlaması; kuramcılar açısından ise yazına ilişkin boşlukların tespiti ve gelecek çalışmalara yön verilmesi açısından önem arz etmektedir. Çalışmanın, başta algılanan örgütsel politika yazının sistematik bir özetini sunarak, ulusal yazında en sık ilişkilendirilen sonuç değişkenlerini tespit etmesi; farklı değişkenlerle ilişkilerin yönünü ve gücünü istatistiki ve bütüncül veriler ışığında ortaya koyması; algılanan örgütsel politikanın ölçümünde en sık kullanılan ölçüm araçlarını saptaması; hem ulusal yazının kuramsal katkı düzeyini yansıtması hem de gelecek çalışmalara rehberlik etmesi açılarından yazına katkı sunması hedeflenmektedir.

Çalışmanın yanıt aradığı temel araştırma soruları şu şekildedir:

1) Ulusal yazın bağlamında, algılanan örgütsel politika en sık hangi sonuç değişkenleriyle ilişkilendirilmektedir?

2) Algılanan örgütsel politika, bu sonuç değişkenleriyle nasıl ve ne düzeylerde bir ilişki göstermektedir?

3) Ulusal yazın bağlamında, algılanan örgütsel politikadan doğan kişi/örgüt düzeyi sonuç değişkenlerinin kümesi nedir ve kuram/pratik açısından vargıları nelerdir?

Bu sorulara yanıt aranırken, bir taraftan da Ferris ve arkadaşlarının (2002) örgütsel politika modeli ışı̆̆ında, ulusal yazında örgütsel politika konusunda yapılan çalışmaların farklılıklarının ve eksiklerinin tespit edilmesi ve gelecek araştırmalara yön tayin edilmesi amaçlanmaktadır. 


\section{Kavramsal Çerçeve}

Ferris ve arkadaşlarının (1989) algılanan örgütsel politika konusunda geliştirdikleri kuramsal model, konuya ilişkin öncülleri, ardılları ve dolaylı etkileri niteleyen en kapsamlı ve öncü model olmuştur. Akabinde, Kacmar ve Ferris (1991) ile Ferris ve Kacmar (1992), algılanan örgütsel politikanın ölçümünde sıklıkla kullanılan POPS (perceived organizational politics scale) ölçeğini geliştirmişlerdir. Ferris ve arkadaşlarının (2002) daha sonra güncelledikleri algılanan örgütsel politika modeli ise hâlihazırda konuya dair en kapsamlı kuramsal model durumundadır. Buna göre, algılanan örgütsel politikanın önde gelen ardılları arasında iş tatmini, iş kaygısı/stresi, geri çekilme (devamsızlık ve işten ayrılma ile işten ayrılma niyeti gibi örüntüler), örgütsel bağlııık, adalet, güven, örgütsel sinizm, iş performansı, örgütsel vatandaşlık ve politik davranışlar bulunmaktadır. Bu sonuç değişkenlerini etkileyen düzenleyiciler ise algılanan kontrol, anlayış, belirsizliğe tolerans, genel öz yeterlilik, göreve ilişkin öz yeterlilik ve politik yeti olarak sıralanmaktadır (Ferris vd., 2002). Ulusal yazında pek dikkate alınmadığını gördüğümüz model, uluslararası yazın bağlamında gerçekleştirilen meta-analiz çalışmalarına da kılavuzluk etmektedir (Atınç vd., 2010).

Örgütsel politika algıları, ulusal yazında çeşitli değişkenlerle ilişkilendirilerek çok defa incelenmiştir. Başar ve arkadaşlarının (2015) çalışması, örgütsel alanda politik algıların işten ayrılma niyetini, ihmalkârlığı ve tükenmişliği pozitif olarak; iş tatmini ve örgütsel özdeşleşmeyi ise negatif olarak etkilediğini ortaya koymuştur. Bir başka çalışmada Başar ve Basım (2016), hemşire örneklemi üzerinde, algılanan örgütsel politikanın işten ayrılma niyeti, ihmalkârlık ve tükenmişlik ile pozitif ilişkilerini ortaya koymuşlardır. Aksoy ve Erdil (2018), algılanan örgütsel politikanın öğretmenlerin örgütsel özdeşleşme düzeyleri üzerinde negatif etkiye sahip olduğunu tespit etmişlerdir. Ayhan ve Gürbüz (2014) kamu çalışanlarının örgütsel politika algılarının örgütsel vatandaşlık davranışını, prosedür adaletini ve etkileşim adaletini olumsuz yönde etkilediğini belirlemişlerdir. Ayhan (2013) tez çalışmasında, algılanan örgütsel politika ile örgütsel adalet ve işten ayrılma niyeti arasındaki ilişkileri incelemiştir. Beyaz yakalılar üzerinde gerçekleştirilen araştırmanın bulgularına göre, algılanan örgütsel politika örgütsel adalet algılarının tüm boyutları ile negatif ve işten ayrılma niyeti ile pozitif yönde ilişkilidir. İşcan (2005) örgütsel politika algılarının çalışanların örgütsel adalet algılarını azalttığını ve işten ayrılma niyetlerini artırdığını belirlemiştir. Başar ve Basım (2015) çalışmasında, algılanan örgütsel politikanın özdeşleşme ve iş tatmini arasındaki ilişkide üstlendiği düzenleyicilik rolü incelenmiş ve politika algılarının iş tatminini olumsuz etkilediği görülmüştür. Eryılmaz ve İspirli (2014) çalışması da politika algıları ile iş tatmini arasındaki negatif ilişkiyi destekler nitelikte sonuçlara ulaşmıştır. Daskin ve Tezer (2012), turizm sektörü çalışanları üzerinde gerçekleştirdikleri çalışmada, politika algılarının işten ayrılma niyetini olumlu yordadığını tespit etmişlerdir. Başar ve Varoğlu (2016), örgütsel politika algılarının işten ayrılma niyetine ve inmalkârlığa yol açtığını belirlemişlerdir. Karatepe ve arkadaşları (2011), politika algılarının otel çalışanlarının tükenmişlik düzeylerini artırdığı sonucuna ulaşmışlardır. Dirik ve arkadaşlarının (2016) üretim sektöründe çalışan beyaz yakalı örnekleminde gerçekleştirilen çalışmasında, algılanan örgütsel politikanın bağlamsal performans ve iş tatmini ile negatif ilişkili olduğu belirlenmiştir. Eryılmaz ve arkadaşlarının (2015) çalışması da politika algılarının bağlamsal performansı negatif etkilediğini doğrulamıştır.

Ulusal yazında yer alan çalışmaların hipotezlerine konu edilen değişkenler arası ilişkiler, bu çalışmanın da çıkış noktasını oluşturmaktadır. Her ne kadar ilişkilerin yönüne ilişkin varsayımlarda bulunmak kolay olsa da ilişkilerin gücünü net olarak ortaya koymak ve ulusal yazın bağ- 
lamında bir model önermek meta-analiz çalışmaları ile mümkün olabilecektir. Mevcut çalışmada algılanan örgütsel politika algıları ile ilişkilendirilen değişkenlerle ilgili beklentileri şu şekilde ifade etmek mümkündür:

AÖP-Iş̧en ayrılma niyeti. İşten ayrılma niyeti, çok çeşitli sebeplerle bireylerin örgütle bağlarını bitirme arzusunu ifade etmektedir. Çalışanlar, örgütte kalmaya devam etseler dahi, işten ayrılma niyetinin ortaya çıkması başlı başına istenmeyen bir örgütsel davranış örüntüsüdür. Ferris ve arkadaşlarının (1989) çalışmasına göre yüksek düzeylerde algılanan örgütsel politikanın bireyde yarattığı hayal kırıklığı, işten ayrılma niyetini pekiştirmektedir. Farklı çalışmalarda, algılanan örgütsel politikanın işten ayrılma niyeti ile ilişkisine dair bulgular yer almaktadır ancak bu çalışmalarda bazen olumlu, bazen olumsuz, bazen ise sıfır ilişki tespit edilmiştir (Miller vd., 2008). Yazındaki yaygın kanaat ise politika algılarının işten ayrılma niyeti ile olumlu yönde ilişkilenmesidir.

AÖP-IŞ tatmini. Ferris ve arkadaşlarının (1989) modelinde öne çıkan en önemli ardıllar iş tatmini, iş stresi ve işten ayrılma niyeti olmuştur. İş tatmini, bireyin işe ilişkin deneyimlerinden elde ettiği pozitif duygulanımları ifade etmektedir. Çok farklı biçimlerde ölçümlenebilen iş tatmininin, algılanan örgütsel politika ile ters yönde ilişkilenmesi beklenmektedir (Miller vd., 2008).

AÖP-Özdeşleşme. Algılanan örgütsel politikanın üretim karşıtı davranışlar arasında sayılması sebebiyle pek çok pozitif örgütsel psikoloji kavramıyla negatif ilişkilenmesi beklenmektedir. Ancak, özdeşleşme, Ferris ve arkadaşlarının (1989) modelinde doğrudan yer almayan bir kavramdır. Ulusal yazında araştırmacılar özdeşleşme ile politika arasındaki ilişkileri irdelemişlerdir (Aksoy ve Erdil, 2018; Başar vd., 2015; Başar vd., 2017; Başar ve Filizöz, 2015). Bu çalışmada, bireyin örgütle kimliklenmesini ve kendi benliğini örgütün varlı̆̆ıyla anlamlandırmasını, kaderini ve geleceğini örgütün geleceği ile bir tutmasını ifade eden özdeşleşme kavramının, algılanan örgütsel politika ile ters yönde ilişkilenmesi beklenmektedir.

AÖP-ihmalkârlık. İhmalkârlık, işten ayrılmayı çeşitli sebeplerle ertelemek zorunda kalan veya işten ayrılamayan çalışanların iş performanslarını minimum seviyeye çektikleri ve işlerini yüksek performans ya da motivasyonla yapmadıkları, memnuniyetsizliklerini ise bir şekilde örgütsel alana yansıttıkları durumu ifade etmektedir. Hatta ihmalkârlık, işten ayrılma niyetinin bir habercisi olarak değerlendirilmektedir (Başar ve Basım, 2016). Algılanan örgütsel politikanın, zaten bir şekilde örgütsel bağlarından rahatsızlık duyan ve kendilerini tehdit altında hisseden çalışanların ihmalkârlık düzeylerine katkıda bulunacağı ve bu anlamda ihmalkârlığın, algılanan örgütsel politika ile pozitif yönde ilişkileneceği ulusal yazındaki çalışmalarda ifade edilmiştir (Başar ve Basım, 2016; Sığrı ve Başar, 2015). Bu çalışmada, algılanan örgütsel politika ile ihmalkârlık arasında pozitif yönde bir ilişki olması beklenmektedir.

AÖP-Tükenmişlik. Tükenmişlik, iş yaşamında deneyimlenen, iyi yönetilmemiş ve kronik stresten kaynaklanan bir sendrom şeklinde tanımlanmaktadır. Enerji yoksunluğu ve tükenmişlik duyguları, işe karşı hissedilen uzaklaşma, olumsuz duygulanım ve duyarsızlaşma ya da işe yabancılaşma ve mesleki yetkinlikteki azalma duyguları veya azalan kişisel başarı olmak üzere tükenmişliğin üç temel boyuttan oluştuğu ifade edilmektedir (Maslach ve Jackson, 1981). Huang vd. (2003) çalışmasında, algılanan örgütsel politikanın işten ayrılma niyeti ile ilişkilenmesine yol açan en önemli faktörün, çalışan bireyde ortaya çıkan tükenmişlik duyguları olduğu ifade edilmiştir. Algılanan örgütsel politikanın, bu alt boyutlardan hepsi ve genel olarak tükenmişlik duyguları ile olumlu yönde ilişkilenmesi, hatta çalışanların tükenmişlik duygularını artırıcı yönde rol oynaması beklenmektedir (Başar vd., 2015; Yüksek ve Bolat, 2016). 
AÖP-Bağlııı. Bireyin çalıştığı örgüte karşı beslediği aidiyet duygusunu tanımlayan ve çok boyutlu bir kavram olan bağlılık (devam bağlıı̆̆ı, normatif bağlılık, duygusal bağlılık gibi), algılanan örgütsel politika ile ters yönde ilişkilendirilmektedir (Ferris vd., 1989; Miller vd., 2008). Farklı alt boyutların algılanan örgütsel politika ile nasıl ilişkileneceği konusu ise özellikle ulusal yazında ihmal edilen bir alan olarak karşımıza çıkmaktadır.

\section{Araştırmanın Yöntemi}

\subsection{Prosedür}

Analizlerin analizi olarak da bilinen meta-analizi, bir konu hakkında daha önce biriken yazının bütüncül bir özetini ortaya koymaya çalışan bir yöntemdir. Görece yakın bir zamanda yaygınlaşan meta-analiz çalışmaları, nicel literatür taramaları olarak da adlandırılmaktadır. Belirli kriterler bağlamında, daha önce gerçekleştirilen ampirik araştırmaların verilerinin bir araya getirilmesi ve derlenen veriden yeni çıkarımlar yapılması, meta-analizinin temel amacını oluşturmaktadır. Bu çalışmada, Hunter ve Schmidt'in (2004) psikometrik meta-analiz yöntemi kullanılmakta ve korelasyon değerleri üzerinden işlem ve yorumlar yapılmaktadır. Korelasyon temelli çalışmaların doğası gereği, bu çalışmaya konu olan ilişkisellik testlerinde de örtük bir nedensellik varsayımı söz konusudur. Çalışmanın değişkenleri arasındaki ilişkilerin istatistiki olarak anlamlılı̆ına karar vermede, etki büyüklüğüne ilişkin güven aralıklarının alt ve üst limitlerinin sıfır değerini içermemesi kriteri gözetilmiştir. Etki büyüklüklerinin gücünü yorumlamada Cohen (1992) tarafından referans gösterilen ve aşağıda ifade edilen eşik değerler referans alınmıştır (Cohen vd., 2007).

Bu çalışmada analizler, CMA meta-analiz programı ile gerçekleştirilmiştir. Çalışmalardan elde edilen korelasyonlar, algılanan örgütsel politika (AÖP)-işten ayrılma niyeti, AÖP-iş tatmini, AÖP-özdeşleşme, AÖP-ihmalkârlık, AÖP-tükenmişlik ve AÖP-bağlılık olmak üzere altı farklı meta-analizde değerlendirilmiştir. Çalışmada, Cohen vd. (2007) tarafından önerilen korelasyona dayalı etki büyüklükleri eşik değerleri referans alınmıştır:

- 0,00 etki büyüklüğü değeri < 0,10 ise çok zayıf düzeyde etki

- 0,11 etki büyüklüğü değeri < 0,30 ise zayıf düzeyde etki

- 0,31 etki büyüklüğü değeri < 0,50 ise orta düzeyde etki

- 0,51 etki büyüklüğü değeri < 0,80 ise güçlü düzeyde etki

- Etki büyüklüğü değeri <0,81 ise çok güçlü düzeyde etki

Korelasyon katsayıları ve örneklem büyüklükleri kullanılarak yapılan meta-analizlerin sonuçları, toplam çalışma sayısı (k), toplam örneklem büyüklüğü (N), Fisher's Z değeri, \%95 güven aralığı için korelasyon değerinin alt ve üst limitleri, heterojenlik testine ilişkin $Q$ değeri, serbestlik derecesi ve $p$ değerleri üzerinden incelenmiştir.

Her ne kadar heterojenlik testine ilişkin sonucun sabit etki modeli ile rassal etki modeli arasında seçim yaparken kullanılabileceği kanısı yaygınsa da, bu çalışmada söz konusu istatistiğin sonucundan ziyade, Field ve Gillett'in (2010) sosyal bilimler alanındaki verilerin doğasının rassal etkiler modeli kullanmayı gerektirdiği yönündeki ifadeleri kılavuz alınmıştır. Tüm metaanalizlerde rassal etki modeline göre sonuçlar raporlanmıştır.

Meta-analizlere dahil edilen çalışmalarda yayın yanlıı̆ı̆ olup olmadığını sınamak üzere Begg ve Mazumdar'ın (1994) sıra korelasyon testi dikkate alınmıştır. Buna göre, Kendall Tau katsayısından edinilen sonucun istatistiksel olarak anlamlı olmasının, yayın yanlılığına işaret edeceği (Field ve Gillett, 2010) kriteri gözetilmiştir. 


\subsection{Veri Analizi}

Çalışmanın cevap aradığı araştırma problemlerini yanıtlamak üzere; Ulakbim TR Dizin, YÖK Ulusal Tez Merkezi, Academic Search Complete, Business Source Complete, Emerald Insight, ERIC, DOAJ, IEEE XploreDigital Library, JSTOR, PsycINFO, Sage Journals Online, Science Direct, Springer Link, Taylor and Francis Online Journals, Wiley Online Library, Clarivate Analytics (Web of Science) veritabanlarında yer alan dergiler ile Ulusal Yönetim ve Organizasyon Kongresi, İşletmecilik Kongresi ve Örgütsel Davranış Kongresi bildiri kitaplarında yer alan Türkiye kaynaklı çalışmalarda "algılanan örgütsel politika", "örgütsel politika algıları", "örgütsel politika", "perceived organizational politics", "organizational politics", "perceptions of politics", "POPs" anahtar sözcüklerini içeren bildiriler, makaleler ve tezler taranmıştır. Ulaşılan yayınların meta-analize dahil edilmesi için a) Çalışmanın ampirik olması, b) Algılanan örgütsel politika ile birtakım öncül veya sonuç değişkenleri arasındaki ilişkiyi incelemesi, c) Söz konusu ilişkilerin yönüne dair bir varsayımda veya çıkarımda bulunulmuş olması, d) Korelasyon katsayılarının ve örneklem büyüklüklerinin raporlanmış olması, e) Verinin Türkiye bağlamında toplanmış olması koşulları baz alınmıştır. Algılanan örgütsel politika ile yakından ilişkili kavramlar olan politik davranışlar, politik yeti ve politik zekâ gibi unsurların ana değişken olduğu yayınların kapsam dışı bırakıldığından ayrıca emin olunmuştur. Arama sonucunda tespit edilen 52 çalışmadan bir kısmı sözü edildiği şekilde algılanan örgütsel politikayı ölçümlemediği veya ampirik bir araştırmaya dayanmadığından ya da aranan istatistiklerin raporlanmamış olması nedeniyle analize dahil edilememiştir. Bazı çalışmalarda ise aynı verinin kullanıldığı tespit edildiğinden, duplikasyon olmaması açısından çalışmalardan yalnızca biri ve tercihen hakemli dergide yayınlanan makaleler analize dâhil edilmiştir (Örneğin, Yüksel'in (2013) doktora tezinden türetilen Yüksel ve Bolat (2016) makale çalışması).

Çalışmanın başlangıcında verilerin kodlanması için oluşturulan excel sayfasında, algılanan örgütsel politika ile ilişkili değişkenin adı, yazar adı ve yayın yılı, örneklem sayısı, korelasyon katsayısı, ölçek ortalaması, standart sapma, yayın türü, örneklem türü, kullanılan ölçüm aracı ve kim tarafından geliştirildiği ve uyarlandığı, katılımcıların cinsiyet dağılımı gibi verilere yer verilmiştir. Analiz aşamasına geçildiğinde bu verilerin tümünden yararlanılmamış olmakla birlikte, çalışmaların niteliğini ve çalışmalarda ulaşılan verilerin/bulguların kalitesini tespit etmek açısından bu ayrıntılı kodlama işlemine başvurulmuştur. Yine çalışmanın başlangıcında, örgütsel politika algısının etkilendiği ve örgütsel politika algılarından etkilenen tüm birey/iş/örgüt düzeyi ilişkilerin ortaya konması hedeflenmiş olsa da araştırma kapsamında ve ulusal yazın bağlamında ulaşılan çalışmalar, örgütsel politika algılarının öncüllerinin metaanalizini yapmayı mümkün kılmamaktadır. Aydın (2015), Çınar-Altıntaş (2007), Eryılmaz ve Altın-Gülova (2017), Yüksel ve Bolat (2016), Akdoğan ve Demirtaş (2014) gibi araştırmacılar algılanan örgütsel politikayı etkileyen "örgütsel muhalefet algısı, kararlara katılım, yetki kademesi, biçimselleşme, örgüt iklimi, güç mesafesi, belirsizlikten kaçınma, bireycilik/çoğulculuk, erillik/dişilik, uzun/kısa dönem, etkileme taktikleri, etik liderlik" gibi çeşitli değişkenlerin farklılaşan ilişkilerini incelemişlerdir. Ancak, bu çalışmalar söz konusu ilişkileri inceleyen tekil verileri teşkil ettiğinden meta-analize uygun bir tablo sunmamaktadır.

Ayrıca, algılanan örgütsel politika, ulusal yazında zorunlu vatandaşlık davranışı (Alkan, 2015), dağıtım adaleti (Ayhan, 2013), işyeri nezaketsizliği (Biçer, 2017), çalışma arkadaşlarına güven (Aksoy ve Erdil, 2018), bağlamsal performans (Dirik vd., 2016), örgütsel vatandaşlık (Ayhan ve Gürbüz, 2014) ve sessizlik (Sağlam Arı, 2011) gibi çok sayıda sonuç değişkeni ile de ilişkilendirilmiştir ancak bu ilişkilere yönelik ampirik araştırma sayıları meta-analiz için yeterli olmadığından kapsam dışı bırakılmışlardır. 
Bazı çalışmalarda birden fazla değişkene ilişkin veri sunulduğu için (örneğin Başar ve Basım (2016) çalışmasında algılanan politikanın hem işten ayrılma niyeti hem de ihmalkârlık ile ilişkisi araştırılmıştır) bu çalışmalar da ayrı birer çalışma gibi düşünülerek toplam çalışma sayısına ilave edilmiştir. Takriben, Ocak 2018 tarihinde başlayan ve Ekim 2018 itibariyle sonlandırılan araştırmalar ve kodlamalar sonucunda, 18 farklı araştırmadan elde edilen $\mathrm{k}=33$ bireysel veri $(\mathrm{N}=12492)$ üzerinden meta-analiz gerçekleştirilmiştir. Bu çalışmaların künyeleri ve araştırma değişkenleri Tablo 1'de sunulmuştur.

\subsection{Araştırmanın Bulguları ve Sonuçları}

Tablo 1'de yer alan verilere göre, algılanan örgütsel politikanın ampirik olarak incelendiği çalışmalar 1997 yılından 2018 yılına kadar zaman açısından yaklaşık yirmi yıllık bir yelpazeyi kapsamaktadır. Algılanan örgütsel politikanın işten ayrılma niyeti ile ilişkilendirildiği dokuz çalışma; iş tatmini ile ilişkilendirildiği dokuz çalışma; özdeşleşme ile ilişkilendirildiği dört çalışma; ihmalkârlık ile ilişkilendirildiği dört çalışma; tükenmişlik ile ilişkilendirildiği dört çalışma ve bağlılık ile ilişkilendirildiği üç çalışma tespit edilmiştir. Meta-analize dâhil edilen çalışmaların sekizi makale, dördü tez ve altısı bildiri türündedir.

Tablo 1: Meta-analize dâhil edilen çalışmalara ilişkin veriler

\begin{tabular}{|c|c|c|c|}
\hline Değişkenler & Yazar adı ve yılı & $\mathbf{N}$ & Türü \\
\hline \multirow{9}{*}{ İşten ayrılma niyeti } & Başar ve Basım (2016) & 456 & Makale \\
\hline & Başar ve Varoğlu (2016) & 314 & Makale \\
\hline & Yüksel ve Bolat (2016) & 644 & Makale \\
\hline & Daşkın ve Tezer (2012) & 140 & Makale \\
\hline & Başar, Alan, Topçu ve Aksoy (2015) & 318 & Bildiri \\
\hline & Sığrı ve Başar (2015) & 216 & Bildiri \\
\hline & Biçer (2017) & 524 & Tez \\
\hline & Ayhan (2013) & 259 & Tez \\
\hline & Doğan (1997) & 58 & Tez \\
\hline \multirow{9}{*}{ İş tatmini } & Başar ve Basım (2015) & 363 & Makale \\
\hline & Yüksel ve Bolat, (2016) & 644 & Makale \\
\hline & Katrinli, Atabay, Günay ve Güneri Çangarlı (2010) & 1401 & Makale \\
\hline & Başar, Alan, Topçu ve Aksoy (2015) & 318 & Bildiri \\
\hline & Eryılmaz ve İspirli (2014) & 264 & Bildiri \\
\hline & Eryılmaz, Dirik ve Köse (2015) & 181 & Bildiri \\
\hline & Dirik, Eryılmaz ve Altın-Gülova (2016) & 171 & Bildiri \\
\hline & Doğan (1997) & 58 & Tez \\
\hline & Biçer (2017) & 524 & Tez \\
\hline \multirow{4}{*}{ Özdeşleşme } & Aksoy ve Erdil (2018) & 405 & Makale \\
\hline & Başar, Sığrı ve Basım (2017 a) & 137 & Bildiri \\
\hline & Başar, Sığrı ve Basım (2017 b) & 119 & Bildiri \\
\hline & Başar, Alan, Topçu ve Aksoy (2015) & 318 & Bildiri \\
\hline \multirow{4}{*}{ İhmalkârlık } & Başar ve Basım (2016) & 456 & Makale \\
\hline & Başar ve Varoğlu (2016) & 314 & Makale \\
\hline & Başar, Alan, Topçu ve Aksoy (2015) & 318 & Bildiri \\
\hline & Sığrı ve Başar (2015) & 216 & Bildiri \\
\hline \multirow{4}{*}{ Tükenmişlik } & Yüksel ve Bolat (2016) & 644 & Makale \\
\hline & Karatepe, Babakuş ve Yavaş (2012) & 620 & Makale \\
\hline & Başar, Alan, Topçu ve Aksoy (2015) & 318 & Bildiri \\
\hline & Sığrı ve Başar (2015) & 216 & Bildiri \\
\hline \multirow{3}{*}{ Bağlılık } & Yüksel ve Bolat (2016) & 644 & Makale \\
\hline & Doğan (1997) & 58 & Tez \\
\hline & Çelik (2017) & 856 & Tez \\
\hline
\end{tabular}


Algılanan örgütsel politikanın işten ayrılma niyeti üzerindeki etkilerini inceleyen çalışmalar üzerine yapılan meta-analizin bulguları, orta düzeyde $(E B=0,393)$ pozitif bir etki büyüklügüne işaret etmektedir. İş tatmini ( $E B=-0,391)$ ve özdeşleşme $(E B=-0,362)$, algılanan örgütsel politika ile orta düzeyde ve negatif ilişkilidir. Algılanan örgütsel politika ihmalkârlık $(E B=0,309)$ ile görece zayıf ve tükenmişlik $(E B=0,408)$ ile orta düzeylerde pozitif ilişkilidir. Son olarak algılanan örgütsel politika, bağııık $(E B=-0,503)$ ile negatif yönde ve orta-güçlü düzeyde ilişkili bulunmuştur.

Tablo 2: AÖP’nin ardıllarına ilişkin etki büyüklükleri

\begin{tabular}{llllllll} 
& & & \multicolumn{2}{l}{ EB'nin \%95 güven aralığı } & \multicolumn{2}{l}{ Heterojenlik testi } \\
\cline { 5 - 8 } Değişkenler & $\mathrm{k}$ & $\mathrm{N}$ & $\mathrm{EB}$ & Alt-üst sınır & Q değeri & sd & $\mathrm{p}$ \\
\hline İşten ayrılma niyeti & 9 & 2929 & 0,393 & $0,255-0,532$ & 108,143 & 8 & 0,000 \\
İş tatmini & 9 & 3924 & $-0,391$ & $(-0,531)-(-0,252)$ & 136,388 & 8 & 0,000 \\
Özdeşleşme & 4 & 979 & $-0,362$ & $(-0,582)-(-0,142)$ & 32,862 & 3 & 0,000 \\
İhmalkârlık & 4 & 1304 & 0,309 & $0,036-0,581$ & 72,976 & 3 & 0,000 \\
Tükenmişlik & 4 & 1798 & 0,408 & $0,253-0,562$ & 57,067 & 4 & 0,000 \\
Bağlılık & 3 & 1558 & $-0,503$ & $(-1,010)-(0,005)$ & 160,194 & 2 & 0,000 \\
\hline
\end{tabular}

$\mathrm{k}=$ analize dahil edilen çalışmaların toplamı, $\mathrm{N}=$ analize dahil edilen çalışmalardaki toplam örneklem sayısı, $\mathrm{EB}=\mathrm{etki}$ büyüklüğü, sd=serbestlik derecesi, p=anlamlılık düzeyi

Heterojenlik testi sonuçlarının anlamlı olması üzerine tüm meta-analizlerde rastgele etki modeli kullanılmıştır. Yayın yanlılığı sorununu aşmak üzere Tau katsayısının anlamlılığı incelenmiştir. Tüm meta-analizlerde söz konusu katsayının $p$ değeri \%95 güven aralı̆̆ında 0,05 eşiğinin üzerinde değerler almıştır. Buna göre, bu araştırmanın kapsamına giren çalışmalarda yayın yanlılı̆ı problemi görülmemektedir.

Tablo 3. Sira korelasyon testi bulguları

\begin{tabular}{llcc}
\hline Değişkenler & $\mathrm{N}$ & Kendall's Tau & $\mathrm{p}$ \\
\hline İşten ayrılma niyeti ile AÖP & 9 & 0,333 & 0,210 \\
İş tatmini ile AÖP & 9 & $-0,444$ & 0,095 \\
Özdeşleşme ile AÖP & 4 & $-1,000$ & 0,061 \\
İhmalkârlık ile AÖP & 4 & 0,000 & 1,000 \\
Tükenmişlik ile AÖP & 4 & 0,300 & 0,462 \\
Bağlılık ile AÖP & 3 & 0,333 & 0,601 \\
\hline
\end{tabular}

Araştırmada yanıt aranan sorular açısından araştırmanın bu kısmında ulaşılan bulgulara ve sonuçlara bakılacak olursa, ulusal yazında AÖP ile en sık ilişkilendirilen sonuç değişkenleri iş tatmini ve işten ayrılma niyeti olarak karşımıza çıkmaktadır. Çalışmadan elde edilen verilere göre AÖP ile ilişkilendirilen sonuç değişkenlerinden en yüksek ilişkili olan örgütsel bağ|ılık (negatif) ve en düşük ilişkili olan inmalkârlıktır (pozitif ilişkili). Bu değişkenlerden örgütsel bağlılık, Ferris ve arkadaşlarının (1989) ilk modelinde de yer alan temel değişkenlerden olmasına karşın, ihmalkârlık (negligence) Ferris ve arkadaşlarının (1989; 2002) modelinde yer almamaktadır. AÖP'nin ilişkili olduğu her bir değişkene ilişkin kuramsal ve pratik vargılar ile değerlendirmeler sonraki kısımda sunulmuştur. 


\section{Sonuç}

Örgütsel yaşamda, bireylerin çıkarlarını öne çıkaran davranışlara yönelmelerinden, örgütsel kararlara ilişkin belirsizlikten, rol dağılımlarının ve çalışanlardan beklentilerin net olmamasından ve kıt kaynaklara dair rekabetten kaynaklandığı yönünde genel bir kanı bulunan örgütsel politika algıları, daha yüksek düzeylerde stres, azalan iş tatmini ve düşük verimlilik gibi istenmeyen sonuçlarla ilişkilendirilmiştir (Miller vd., 2008). Ferris ve arkadaşlarının (1989) algılanan örgütsel politika konusunda kült sayılabilecek olan makalelerini yayınlamalarından bu yana geçen yaklaşık otuz yıllık süre zarfında, hem AÖP'nin ölçülmesine ilişkin çeşitli araçlar geliştirilmiş (Ferris ve Kacmar, 1992; Kacmar ve Carlson, 1997) hem de AÖP'nin örgüt-birey düzeyinde etkileri çok sayıda çalışmaya konu olmuştur. Bu çalışmalarda ulaşılan sonuçlara ilişkin bütüncül bir bakış açısı geliştirilmesini sağlayacak türden değerlendirmeler ve metaanaliz çalışmaları ise uluslararası yazında yer almaya devam etmektedir (Atınç vd., 2010; Ferris vd., 2002; Miller vd., 2008). Bu çalışmada ise algılanan örgütsel politikaya dair ulusal yazında gerçekleştirilen çalışmaların analitik bir süzgeçten geçirilerek özetlenmesi ve birey/örgüt bağlamında etkilerinin değerlendirilmesi hedeflenmiştir.

\subsection{Teorik Katkılar}

Işsten ayrılma niyeti-AÖP. Ferris ve arkadaşlarına (1989) göre yüksek düzeylerde AÖP'nin yol açtığı hayal kırıklığı ve kırgınlık, bireyleri işten ayrılma arzusuna sevk etmektedir. Örgütte var olan politikayla başa çıkamadıkça adalet ve hakkaniyet duyguları zedelenen bireyler (Cropanzano vd., 1997) işten ayrılma düşüncesine yönelmektedir. Ulusal yazında yapılan çalışmalar da bu önermeyi desteklemektedir (Ayhan, 2013; Başar ve Basım, 2016; Yüksel ve Bolat, 2016). Meta-analiz bulgularına göre politika algılarının işten ayrılma niyeti üzerindeki etkisi pozitif yönde orta düzeylerdedir.

IŞ tatmini-AÖP. Ferris ve arkadaşlarının (1989) kuramsal modelinde işaret ettiği üzere iş tatmini ile AÖP arasında ters yönlü bir ilişki vardır. Ferris ve Kacmar (1992), Parker ve arkadaşları (1995), Zhou ve Ferris (1995), Cropanzano ve arkadaşları (1997), Randall ve arkadaşları (1999), Valle and Perrewé (2000), Vigoda (2001) ile Witt ve arkadaşları (2000) tarafından yapılan çalışmalar, iş tatmininin algılanan örgütsel politika ile negatif ilişkisine farklı bağlam ve zamanlardan kanıt getirmektedir. Ulusal yazında yer alan çalışmalar da bu ilişkiyi ve yönünü doğrular niteliktedir (Dirik vd., 2016; Doğan, 1997; Eryılmaz vd., 2015; Eryılmaz ve İspirli, 2014; Katrinli vd., 2010). Meta-analiz bulgularına göre politika algılarının iş tatmini üzerindeki etkisi negatif yönde orta düzeylerdedir.

Özdeşleşme-AÖP. Özdeşleşme, Ferris ve arkadaşlarının (1989; 2002) algılanan örgütsel politika modellerinde yer almamış bir sonuç değişkenidir. Her ne kadar, algılanan örgütsel politikayı şekillendiren işe ilişkin/çevresel faktörler arasında "katılım/dahiliyet" (participation/involvement) yer alıyor olsa da özdeşleşme konusu modelin içerisinde doğrudan yer bulmamaktadır. Ulusal yazındaki çalışmalarda, örgütsel bağlılık, iş tatmini, iş performansı ve örgütsel vatandaşlık gibi sıklıkla olumluluğuna vurgu yapılan iş davranışlarının AÖP ile negatif ilişkilenmesi bağlamında, kişinin örgütü ailesi gibi benimsemesi, aidiyet hissetmesi ve kabullenmesi olarak ifade edilen özdeşleşmenin de benzer biçimde negatif yönde bir ilişki sergileyeceği öngörülmüştür (Aksoy ve Erdil, 2018; Başar ve Filizöz, 2015). Yine, algılanan örgütsel politikanın yarattığı olumsuz duygulanımların, kişinin örgütsel değerlerle ve örgütün kimliğiyle kendi kimliği arasındaki bağı zayıflatacağı, bu anlamda örgütten uzaklaşan bireyin örgütsel bağııığının yanı sıra örgütle özdeşleşmesinin de zedeleneceği araştırmacılarca öne sürülmüş- 
tür (Aksoy ve Erdil, 2018; Başar ve Basım, 2015). Bu meta-analiz çalışmasının bulguları, özdeşleşmenin AÖP ile orta düzeylerde negatif ilişkilendiğini doğrulamaktadır.

ihmalkârlık-AÖP. Bu meta-analizin bulgularına göre ihmalkârlık, algılanan örgütsel politika ile pozitif yönde ve en zayıf ilişkilenen sonuç değişkeni olmuştur. İşten ayrılma niyetinin alternatifi ve bir adım öncesi olarak değerlendirilen ihmalkarlık (Başar ve Basım, 2016), bireyin her türlü memnuniyetsizliğine, motivasyon ve inanç kaybına karşın, başka iş bulamama veya örgütü bir şekilde cezalandırma isteği duyma gibi gerekçelerle örgütte kalmaya devam etmesini ancak sürekli olarak hoşnutsuzluğunu dile getirmesini ifade eden bir kavramdır. Örgüte hâkim olan politik algılardan rahatsız olan ve kendini tehdit altında hisseden çalışanların, işten ayrılmasalar dahi işi kasıtlı olarak inmal edecekleri ulusal yazındaki çalışmalarda öne sürülmüş ve doğrulanmıştır (Başar ve Basım, 2016; Sığrı ve Başar, 2015).

Tükenmişlik-AÖP. Algılanan örgütsel politikanın işten ayrılma niyeti ve devamsızlık gibi sonuçlar doğurduğuna ilişkin tartışma Ferris ve arkadaşları (1989; 2002) tarafından yapılmış olsa da, tükenmişlik, algılanan örgütsel politika modelinin bir parçası değildir. Ancak, Cropanzano ve arkadaşlarının (1997) çalışması genel yorgunluğun, gerginliğin ve somatik problemlerin yanı sıra tükenmişliğin de AÖP'nin bir sonucu olduğunu tespit etmiştir. Ulusal yazında AÖPtükenmişlik ilişkisine bakıldığında (Başar vd., 2015; Yüksek ve Bolat, 2016), yüzyılın başat ve bulaşıcı meslek hastalıklarından biri olarak nitelenen tükenmişliğin (Karatepe vd., 2012) bir stres faktörü olarak bireyin omzundaki psikolojik yükü artıran algılanan örgütsel politikadan etkilendiği belirtilmektedir. Benzer biçimde, Mintzberg (1983) algılanan örgütsel politikayı "örgütsel bir hastalık" olarak nitelemiştir. Bu meta-analiz çalışmasının bulguları, algılanan örgütsel politikanın tükenmişlik üzerinde pozitif ve orta düzeyde etkili olduğunu göstermektedir.

Bağlılık-AÖP. Kişinin, belirli bir örgütün parçası olma konusunda duyduğu güçlü istek olarak tanımlanan ve çok boyutlu (devam bağ|ı|ı̆ı, normatif bağlılık, duygusal bağlıık) bir yapı olarak ele alınan bağlıığın, algılanan örgütsel politika ile ters yönlü ilişkilendiği Ferris ve arkadaşları (1989; 2002) tarafından ifade edilmiştir. Devam bağlılığı ve duygusal bağlılığın algılanan örgütsel politikadan anlamlı etkilenmediği yönündeki bulgulara ek olarak (Randall vd., 1999), negatif etkileşime kanıt getiren araştırmalar da yazında mevcuttur (Witt, 1998). Ulusal yazında yapılan çalışmalar da bağlıı̆̆ın örgütsel politika algıları ile negatif ilişkilendiğine işaret etmektedir (Çelik, 2017; Yüksel ve Bolat, 2016). Miller ve arkadaşlarının (2008) İngilizce yayınlar üzerine yaptıkları meta-analiz çalışmasında, bağlılık konusunun AÖP ile ilişkisine dair çalışmaların bağlılık konusunu ekseriyetle tek boyutlu olarak ele almaları eleştiri konusu yapılmaktadır. Ulusal yazında da bağııı̆ın alt boyutları ile yapılan çalışmaların eksikliği dikkati çekmektedir. Bu çalışmada, genel olarak bağıılığın AÖP ile orta düzeylerde negatif ilişkilendiği doğrulanmıştır.

\subsection{Gelecek Araştırmalara Yönelik Katkılar}

Çalışma kapsamında incelenen araştırmalardan yola çıkılarak ulaşılan başat bir bulgu, araştırmaların neredeyse tamamında ithal araçlara dayalı nicel yöntemin kullanılmış olmasıdır. En sık kullanılan ölçek Hochwarter (2003) tarafından geliştirilen ve Akdoğan \& Demirtaş (2014) tarafından uyarlanan altı maddelik tek boyutlu ölçek olarak görülmektedir. Uluslararası yazında yapılan meta-analizlerde ise Kacmar ve Carlson'ın (1997) 12 maddelik ölçeği öne çıkmaktadır. Ulusal yazında, algılanan örgütsel politikanın ölçümüne yönelik bağımsız bir ölçek geliştirme çabası da görülmemektedir. Yine, kullanılan nicel araçlar da kendi içerisinde çeşitlilik göstermektedir. Bu durum, örgüt araştırmaları kapsamında kullanılabilecek, kültüre özgü standart 
bir ölçüm aracına duyulan ihtiyacı ortaya koymaktadır. İncelenen tekil çalışmalarda göze çarpan bazı eksiklikler ise özellikle ters kodlanan maddelere ilişkin bilgilerin bazen raporlanmaması ve orijinal ölçeğe veya uyarlamayı yapana atıf verilmemesidir. Ölçeği, tek boyut kullanan çalışma, boyutlandırarak kullanan çalışmadan daha fazladır.

Bu çalışmada, algılanan örgütsel politika ile ilişkilendirilen değişkenlerin hiçbiri güçlü-çok güçlü bir etki büyüklügü göstermemiştir. Bu durumun olası nedenleri ise 1) politikaya her iki uçta fazlasıyla toleranslı oluşumuz ve ölçülü tepkiler vermemiz, 2) ölçüm araçlarını sorgulamamız gerekliliği olarak değerlendirilmektedir. Zira uluslararası meta-analizlerde bizden farklı olarak sıfır ilişki ve güçlü ilişkiler tespit edilmektedir. Algılanan örgütsel politikanın sonuç değişkenleri ile ilişkisinde öngörülmeyen yönde bir ilişki de ortaya çıkmamıştır. Tüm bulguların "kitabına uygun" olması da Türk yazınının uluslararası yazından farklılaştığı bir nokta olarak karşımıza çıkmaktadır. Hiçbir tekil veride beklenenin aksine/anlamsız ilişkiler ve bulgular söz konusu olmamıştır. Bu durum, yayın yanlılığı sorunsalını bir kez daha gündeme getirmekte ve istenmeyen sonuçlar ortaya koyan araştırmaların yayımlanmaması ihtimalini düşündürmektedir.

Araştırmalar, kişilik özelliklerinin örgütsel politika algılarındaki değişkenliği açıklayan güçlü bir yordayıcı olduğuna işaret etmektedir (Adams vd., 2008). Makyavelist kişilik yapısının, Makyavelistlerin insan doğası hakkındaki sinik düşünceleri ve kişisel faydaları adına aşırı cüretkâr olabilmeleri gibi özellikleri nedeniyle, örgütsel politika algıları ile pozitif ilişkili olduğu tespit edilmiştir (Valle ve Perrewe, 2000). Kontrol odakları açısından, iç kontrol odağı yüksek ve çevresinin yönetiminde söz sahibi olduğuna inanan kimselerin örgütsel politika algılarının görece daha düşük olduğu; dış kontrol odaklıların ise dışsal faktörlerin etkisi karşısında duydukları çaresizlik nedeniyle politika algılarının daha yoğun olduğu araştırmalara konu edilmiştir (Atınç vd., 2010). Yine, pozitif duygulanımı yüksek kimselerin, negatif duygulanımı yüksek olanlara kıyasla, çevrelerini olumlu bir pencereden görme isteklilikleri nedeniyle örgütsel politika algılarının daha düşük olacağı belirtilmektedir (Adams vd., 2008; Ferris vd., 2002). Örgütsel politika algılarının öncülleri üzerine uluslararası yazında yapılan bir meta-analiz çalışmasında (Atınç vd., 2010), örgütsel değişkenler, iş çevresine ilişkin değişkenler ve kişisel değişkenler olmak üzere üç öncül grubu tanımlanmıştır. Etki katsayılarına göre, en önemli öncüller grubunun iş çevresine ilişkin (sırasıyla lider-üye etkileşimi, kararlara katılım, iş arkadaşlarına güven, beklentilerin karşılanması, ilerleme fırsatları ve gelişim olanakları) değişkenlerden oluştuğu tespit edilmiştir. Aynı çalışmanın bulgularına göre, örgütsel değişkenler kategorisinde yer alan süreç adaleti algıları (negatif), örgütün merkezileşme derecesi (pozitif) ve biçimselleşme derecesi (negatif) ile kişisel değişkenler grubunda yer alan Makyavelizm (pozitif), dış kontrol odağı (pozitif), pozitif duygulanım (negatif) ve negatif duygulanım (pozitif) da algılanan örgütsel politika ile ilişkilenmektedir.

Bu noktaya kadar ele alınan sonuç değişkenleri ve ilişkiler, algılanan örgütsel politikanın çok çeşitli faktörlerden etkilenmesine karşın sonuçta "birey" düzeyinde gerçekleştiği varsayımına dayanmaktadır. Ancak, araştırmacılar, örgüt düzeyi faktörlerin önemine ithafla, bir tür "örgüt düzeyi algılanan örgütsel politika modeli" geliştirilmesi yönündeki ihtiyaca değinmektedir (Atınç vd., 2010; Dipboye ve Foster, 2002). Bu açıdan, belirli insan kaynakları uygulamalarının algılanan örgütsel politika ve dolayısıyla başka sonuçlar üzerindeki etkilerinin incelenmesi gerektiği ve bu türden İK uygulamalarının algılanan örgütsel politikanın yol açabileceği olumsuzlukları giderme ve örgütsel etkililiği artırma potansiyeli (Ferris vd., 1998) üzerine gidilmesi gereken konular olarak değerlendirilmektedir. 


\subsection{Pratik/Uygulamaya Yönelik Katkılar}

Algılanan örgütsel politika araştırmaları, politikayı çalışanların bakış açısına sıkıştırmış görünmektedir. Yöneticilerin bakış açısının ihmal edilmesi anlamına gelen bu yaklaşım, astların algıladığı politika ile yöneticilerin algıladığı politika arasındaki olası farklıııkları da ihmal etme sonucunu doğurmaktadır. Bu durum, bir örgüte dışarıdan atanan bir yeni yöneticinin algılayabileceği örgütsel politikanın da pekâlâ araştırma konusu yapılabileceğini yadsımaktadır.

Yazın, algılanan örgütsel politikayı etkileyen çok çeşitli değişkenlere işaret etmektedir. Örgüt içinde iş arkadaşlarına güven ve kaliteli ilişkilerin varlığına yönelik inanç, diğerlerinin kendi çıkarlarına yönelik davranışlara yönelmeyeceği düşüncesini pekiştirerek algılanan örgütsel politikayı azaltmaktadır. Bu bağlamda araştırmalar, güven ile algılanan örgütsel politika arasında negatif yönlü ilişkiler olduğunu göstermektedir (Howell, 2005; Parker vd., 1995). Yine, üstlerle kurulan kaliteli etkileşimler veya lider-üye etkileşiminin yüksek olması durumunun, çalışanların algıladığı örgütsel politika düzeyini azalttığı belirtilmiştir (Collins, 2008; Kacmar vd., 2007). Aksine, dış grupta yer almak ise iç grup üyelerine yönelik muamelenin hakkaniyetten ziyade iltimasçılıktan beslendiği ve politik kaygılarla ortaya çıktığı izlenimini perçinleyerek, örgütsel politika algılarını tetikleyici rol oynayacaktır. Bu meta-analiz çalışmasının gösterdiği üzere algılanan örgütsel politika, işten ayrılma niyeti, ihmalkârlık, tükenmişlik gibi olumsuz tutumlara yol açmaktadır. Bunlardan kaçınma noktasında uygulamacılara bu türden biçimsel ve biçimsel olmayan mekanizmaları geliştirmeleri önerilmektedir.

Nihayet, bu meta-analiz çalışmasının sonuçlarına dayanarak, algılanan örgütsel politikanın iş tatmini, özdeşleşme, bağlılık gibi örgütçe arzulanan sonuçları olumsuz etkilemesi gerçeğinden hareketle, uygulamacılara, istihdam kararlarında kişi-örgüt uyumunu dikkate almaları ve çalışanların kişisel özelliklerini gözeten politikalar izlemeleri önerilmektedir.

\subsection{Kısıtlılıklar}

Bu çalışmada, algılanan örgütsel politikanın çalışma yaşamında yol açabileceği birtakım sonuçların, ampirik araştırmalar üzerinden sistematik biçimde incelenmesi hedeflenmiştir. Ancak çalışmada, algılanan örgütsel politikanın öncülleri veya sonuç değişkenlerini etkileyen aracı-düzenleyici değişkenler göz ardı edilmiştir. Bu anlamda çalışma, algılanan örgütsel politikanın ulusal yazında nomolojik ağını ortaya koymak gibi geniş çaplı bir hedeften ziyade, daha dar kapsamlı bir amaca hizmet etmektedir. Yine algılanan örgütsel politika aracılığıyla şekillenen sonuçlar üzerine çıkarımlar da yapılamamıştır. Bu durumun en önemli gerekçesi ise algılanan örgütsel politikanın öncülleri ve algılanan örgütsel politikanın aracılık ettiği/düzenlediği değişkenler üzerine ulusal yazında yeterince ampirik araştırma bulunmamasıdır.

Algılanan örgütsel politikanın sonuç değişkenleri ile ilişkisinin doğrudan olmadığı veya çeşitli bağımsız değişkenlerden etkilendiği koşullar bu meta-analizin kapsamı dışında kalarak bir kısıt olarak ortaya çıkmıştır. Ferris ve arkadaşları (2002) kişinin mensubu olduğu etnik grubun veya yaş değişkeninin örgütsel politika algıları üzerinde etkili olduğuna işaret etmektedir. Buna göre, azınlıklar ve daha yaşlı bireyler, daha yüksek düzeylerde örgütsel politika algılamakta ve bu durum olumsuz sonuçlara yol açmaktadır. Yine yazarlar, istihdam koşullarının ve kültürel farklııkların politika algılarını biçimlendirdiğini ifade etmektedir. Algılanan örgütsel politikanın, kamu kurumları ile özel sektör işletmeleri arasında, yabancı bir ülkede çalışan kişiler ile anavatanında çalışan kişiler arasında ve verinin üstlerden ya da astlardan toplanmış olması durumları açısından farklılık göstereceği de belirtilmektedir (Miller vd., 2008). 


\section{Eskişehir Osmangazi Üniversitesi IïB Dergisi}

Çalışmanın en büyük kısıtılığı, uygun verileri içeren tüm çalışmaların analize dâhil edilmiş olmasıdır. Meta-analize dâhil edilen yayınların kalitesinin aslında bu çalışmanın kalitesinde de belirleyici rol oynadığının altını çizmek gerekmektedir. Yine meta-analiz çalışmalarının en büyük kısıtlılıklarından biri çekmecede unutulan yayınlar sorunsalıdır. Meta-analize dâhil edilen çalışmaların tümü aynı ölçüm araçlarını ve benzer örneklemleri kullanmamaktadır. Bu durum hem bir avantaj hem de bir kısıtlılık sebebidir. Diğer taraftan, verilerin toplandığı dönemlerin ve toplumsal, ekonomik, kültürel bağlamların farklılı̆ı bütüncül çıkarımlar yapmanın uygunluğunu şüpheli hale getirmektedir. Tüm bu sınırlılıklara karşın bu çalışma, algılanan örgütsel politika konusunda ulusal yazının mevcut durumunu özetleyen en kapsamlı ve güncel bilimsel çalışma olarak yazına mütevazı bir katkı sunmayı hedeflemektedir.

\section{Kaynaklar}

Meta-analize dahil edilen çalışmalar * ile gösterilmiştir.

Adams, Garry L.; Treadway, Darren C.; Stepina, Lee P. (2008), "The Role of Dispositions in Politics Perception Formation: The Predictive Capacity of Negative and Positive Affectivity, Equity Sensitivity, and Self-Efficacy", Journal of Managerial Issues, Vol. 20, No. 4: 545-563.

Akdoğan, Asuman; Demirtaş, Özgür (2014), “Etik Liderlik Davranışlarının Etik İklim Üzerindeki Etkisi: Örgütsel Politik Algılamaların Aracı Rolü", Afyon Kocatepe Üniversitesi iiBF Dergisi, C. 16, S. 1: 107-123.

*Aksoy, Seval; Erdil, Oya (2018), "Do In-House Policy Perceptions of Teachers Working at State Schools Affect Their Identification with the Institution?" Research Journal of Business and Management, Vol. 5, No. 2: 150-169.

Alkan, Suzan Ece (2015), “A Research About the Relationship of Psychological Safety and Organizational Politics Perception With Compulsory Citizenship Behavior," Yayınlanmamış Yüksek Lisans Tezi, Marmara Üniversitesi Sosyal Bilimler Enstitüsü, İstanbul.

Atinç, Güçlü; Darrat, Mahmoud; Fuller, Bryan; Parker, Barry W. (2010), "Perceptions of Organizational Politics: A Meta-Analysis of Theoretical Antecedents", Journal of Managerial Issues, Vol. 22, No. 4: 494-513.

Aydın, Mümin Ali (2015), "Sınıf Öğretmenlerinin Örgütsel Muhalefet, Örgütsel Politika ve Politik Davranış Algıları Arasındaki İlişki", Yayımlanmamış Yüksek Lisans Tezi, Abant İzzet Baysal Üniversitesi Eğitim Bilimleri Enstitüsü, Bolu.

*Ayhan, Özgür (2013), "Algılanan Örgütsel Politikanın Örgütsel Adalet ve İşten Ayrılma Niyetine Etkisi”, Yayınlanmamış Yüksek Lisans Tezi, Gebze Yüksek Teknoloji Enstitüsü, Kocaeli.

*Başar, Ufuk; Alan, Hale; Topçu, Mustafa Kemal; Aksoy, Seval (2015), “Örgütsel Politika Algısının Ardılları Üzerine Görgül Bir Araştırma", 3. Örgütsel Davranış Kongresi, Tokat.

*Başar, Ufuk; Basım, Hamdullah Nejat (2015), "Effects of Organizational Identification On Job Satisfaction: Moderating Role Of Organizational Politics", Yönetim ve Ekonomi, C. 22, S. 2: 663-683.

*Başar, Ufuk; Basım, Hamdullah Nejat (2016), “A Cross-Sectional Survey on Consequences of Nurses' Burnout: Moderating Role of Organizational Politics", Journal of Advanced Nursing, Vol. 72, No. 8: 1838-1850.

*Başar, Ufuk; Sığrı, Ünsal; Basım, Hamdullah Nejat (2017), “Etik Liderlik Algısının Örgütsel Özdeşleşme Üzerindeki Etkisinde Örgütsel Politika Algısının Düzenleyici Rolü”, 5. Örgütsel Davranış Kongresi, Antalya.

*Başar, Ufuk; Varoğlu, Abdülkadir (2016), “Örgütsel Politika Algısının İhmalkârlık Üzerindeki Etkisinde İşten Ayrılma Niyetinin Aracı Rolü”, Yönetim ve Ekonomi, C. 23, S. 3: 751-765.

Begg, Colin B.; Mazumdar, Madhuchhanda (1994), "Operating Characteristics of A Rank Correlation Test For Publication Bias", Biometrics, Vol. 50, No. 4: 1088-1101.

*Biçer, Can (2017), “Örgütsel Politika Algısının İşyeri Arkadaşlığına Etkisi ve Bireysel Sonuçları”, Yayınlanmamış Doktora Tezi, Karabük Üniversitesi Sosyal Bilimler Enstitüsü, Karabük.

Chang, Chu-Hsiang; Rosen, Christopher C.; Levy, Paul E. (2009), "The Relationship Between Perceptions of Politics and Employee Attitudes, Strain, and Behavior: A Meta-Analytic Examination", Academy of Management Journal, Vol. 52, No. 4: 779-801.

Cohen, Louis; Manion, Lawrence; Morrison, Keith (2007), Research Methods in Education (6th ed.), New York, NY, US: Routledge/Taylor \& Francis Group. 
Collins, Brian J. (2008), “One Size Does Not Fit All: Nurturing or Neglecting the Nature of an Individual's Core SelfEvaluation", Thesis, University of Alabama.

Cropanzano, Russell; Howes, John C.; Grandey, Alicia A.; Toth, Paul (1997), "The Relationship of Organizational Politics and Support To Work Behaviors, Attitudes, and Stress", Journal of Organizational Behavior, Vol. 18, No. 2: 159180 .

*Çelik, Osman Tayyar (2017), “Ortaokul Öğretmenlerinin Örgütsel Politika Algılarıyla Örgütsel Bağlılıkları ve Örgütsel Vatandaşlık Davranışları Arasındaki İlişkinin Analizi”, Yayınlanmamış Doktora Tezi, İnönü Üniversitesi Eğitim Bilimleri Enstitüsü, Malatya.

Çınar-Altıntaş, Füsun (2007), “Örgüt Yapısının Örgütsel Politika ve İşlem Adaleti Üzerine Etkisinin Yapısal Denklem Modellemesi Yardımıyla Analizi”, Anadolu Üniversitesi Sosyal Bilimler Dergisi, C. 7, S. 2: 151-168.

*Daskin, Mustafa; Tezer, Murat. (2012), “Organizational Politics and Turnover: An Empirical Research From Hospitality Industry", Tourism: An International Interdisciplinary Journal, Vol. 60, No. 3: 273- 291.

Dipboye, Robert L.; Bigazzi-Foster, Jessica (2002), "Multi-Level Theorizing About Perceptions of Organizational Politics", (Ed. Francis J. Yammarino; Fred Dansereau), The Many Faces of Multi-Level Issues (Research in Multi-Level Issues Vol. 1), Emerald Group Publishing Limited: 255-270.

*Dirik, Deniz; Eryılmaz, İnan; Altın-Gülova, Asena (2016), “Liderin Güç Kaynakları, İş Tatmini ve Bağlamsal Performans Arasındaki İlişkide Örgütsel Politikanın Rolü”, 4. Örgütsel Davranış Kongresi, Adana.

*Doğan, Ercüment (1997), “Örgütsel Politika Algısının Beş Örgütsel Davranış Değişkeni ve Makyavelizm İle Olan İlişkisi”, Yayınlanmamış Yüksek Lisans Tezi, Marmara Üniversitesi Sosyal Bilimler Enstitüsü, İstanbul.

Ertekin, Yücel; Yurtsever-Ertekin, Gülçimen (2003), Örgütsel Politika ve Taktikler, Ankara: Türkiye ve Ortadoğu Amme İdaresi Enstitüsü.

Eryılmaz, İnan; Altın-Gülova, Asena (2017), “Örgüt İkliminin, Algılanan Örgütsel Politika Üzerine Etkisi: Kamu Sektöründe Bir Araştırma", Manisa Celal Bayar Üniversitesi Sosyal Bilimler Dergisi, C. 15, S. 4: 155-176.

*Eryılmaz, İnan; Dirik, Deniz; Köse, Sevinç (2015), “Kişilik Faktörleri ve Bağlamsal Performans Arasındaki Illişkide Algılanan Örgütsel Politikanın Rolü”, 3. Örgütsel Davranış Kongresi, Tokat.

*Eryılmaz, İnan; İspirli, Deniz (2014), “Algılanan Örgütsel Politikanın İş Tatminine Etkisi: Örgüt İkliminin Aracılık Rolü”, 2. Örgütsel Davranış Kongresi, Kayseri.

Ferris, Gerald R.; Adams, Garry; Kolodinsky, Robert W.; Hochwarter, Wayne A.; Ammeter, Anthony P. (2002), "Perceptions of Organizational Politics: Theory and Research Directions", (Ed. Francis J. Yammarino; Fred Dansereau), The Many Faces of Multi-Level Issues (Research in Multi-Level Issues, Vol. 1), Emerald Group Publishing Limited: 179-254.

Ferris, Gerald R.; Frink, Dwight D.; Galang, Maria Carmen; Zhou, Jing; Kacmar, K. Michele; Howard, Jack L., (1996), "Perceptions of Organizational Politics Prediction: Stress-Related Implications and Outcomes", Human Relations, Vol. 49, No. 2: 233-266.

Ferris, Gerald R.; Kacmar, K. Michele (1992), “Perceptions of Organizational Politics”, Journal of Management, Vol. 18, No. 1: 93-116.

Ferris, Gerald R.; Russ, Gail S.; Fandt, Patricia M. (1989), "Politics In Organizations”, (Ed. Robert Giacalone; Paul Rosenfeld), Impression Management in the Organization, Hillsdale, NJ: Lawrence Erlbaum: 143-170.

Ferris, Gerald. R; King, R. Thomas (1991), "Politics In Human Resources Decisions: A Walk on the Dark Side", Organizational Dynamics, Vol. 20, No. 2: 59-72.

Ferris, Gerald. R.; Arthur, Michelle M.; Berkson, Howard M.; Kaplan, David M.; Harrell-Cook, Gloria; Frink, Dwight D. (1998), "Toward A Social Context Theory of the Human Resource Management-Organization Effectiveness Relationship" Human Resource Management Review, Vol. 8, No. 3: 235-264.

Field, Andy P.; Gillett, Raphael (2010), "How to Do A Meta-Analysis", British Journal of Mathematical \& Statistical Psychology, Vol. 63, No. 3: 665-694.

Gandz, Jeffrey; Murray, Victor V. (1980), "The Experience of Workplace Politics", Academy of Management Journal, Vol. 23, No. 2: 237-225.

Howell, Sharon K. (2005), "Adaptive Self-regulation and Organizational Politics: Investigating the Effects in the Accounting Profession", Thesis, University of Central Florida.

Huang, I.; Chuang, C. J.; Lin, H. (2003), "The Role of Burnout in the Relationship Between Perceptions of Organizational Politics and Turnover İntentions", Public Personnel Management, Vol. 32: 519-530. 


\section{Eskişehir Osmangazi Üniversitesi IïB Dergisi}

Hunter, John E.; Schmidt, Frank L. (2004), Methods of Meta-Analysis: Correcting Error and Bias in Research Findings, $2^{\text {nd }}$ Ed., Beverly Hills, CA: Sage.

İşcan, Ömer Faruk (2005), "Siyasal Arena Metaforu Olarak Örgütler ve Örgütsel Siyasetin Örgütsel Adalet Algısına Etkisi", Ankara Üniversitesi SBF Dergisi, C. 60, S. 1: 149-171.

Kacmar, K. Michele; Carlson, Dawn S. (1997), "Further Validation of the Perceptions of Politics Scale (POPS): A Multiple Sample Investigation", Journal of Management, Vol 23, No. 5: 627- 658.

Kacmar, K. Michele; Ferris, Gerald R. (1991), "Perceptions of Organizational Politics Scale (POPS): Development and Construct Validation", Educational and Psychological Measurement, Vol. 51, No. 1: 193-205.

Kacmar, K. Michele; Zivnuska, Suzanne; White, Charles D. (2007), "Control and Exchange: The Impact of Work Environment on the Work Effort of Low Relationship Quality Employees", The Leadership Quarterly, Vol. 18, No. 1: 69-84.

*Karatepe, Osman M; Babakuş, Emin; Yavaş, Uğur (2011), “Affectivity and Organizational Politics As Antecedents of Burnout Among Frontline Hotel Employees”, International Journal of Hospitality Management, Vol. 31: 66-75.

*Katrinli, Alev; Atabay, Gülem; Günay, Gonca; Güneri-Çangarlı, Burcu. (2010), "Perceptions of Organizational Politics and LMX: Linkages In Distrubutive Justice and Job Satisfaction", African Journal of Business Management, Vol. 4, No. 14: 3110-3121.

Maslach, Christina; Jackson, Susan E. (1981), "The Measurement of Experienced Burnout", Journal of Organizational Behavior, Vol. 2, No. 2: 99-113.

Miller, Brian K.; Rutherford, Matthew A.; Kolodinsky, Robert W. (2008), "Perceptions of Organizational Politics: A Meta-Analysis of Outcomes", Journal of Business and Psychology, Vol. 22, No. 3: 209-222.

Mintzberg, Henry (1983), Power In and Around Organizations, Englewood Cliffs, NJ: Prentice-Hall.

Mohan-Bursalı, Yeliz (2008), “Örgütsel Politikanın İşleyişi: Örgütsel Politika Algısı ve Politik Davranış Arasındaki İlişkiler”, Yayınlanmamış Doktora Tezi, Dokuz Eylül Üniversitesi Sosyal Bilimler Enstitüsü, İzmir.

Parker, Christopher; Dipboye, Robert L.; Jackson, Stacy L. (1995), “Perceptions of Organizational Politics: An Investigation of Antecedents and Consequences", Journal of Management, Vol. 21, No. 5: 891-912.

Pfeffer, Jeffrey (1981), Power In Organizations, Marshfield, MA: Pitman.

Porter, Lyman W.; Allen, Robert W; Angle, Harold L. (1981), "The Politics of Upward Influence In Organizations", (Ed. Larry L. Cummings; Barry M. Staw), Research In Organizational Behavior Vol. 3, New York: Academic Press: 109-149.

Randall, Marjorie L.; Cropanzano, Russell; Bormann, Carol A.; Birjulin, Andrej (1999), "Organizational Politics and Organizational Support As Predictors of Work Attitudes, Job Performance, and Organizational Citizenship Behavior", Journal of Organizational Behavior, Vol. 20, No. 2: 159-174.

Sağlam-Arı, Güler (2011), "Politik Arenada Sessiz Kalanlar: Örgütsel Politika ve Örgütsel Sessizlik Arasındaki Illişkide Birey Örgüt Uyumunun Düzenleyici Etkisi Üzerine Bir Araştırma”, 19.Ulusal Yönetim ve Organizasyon Kongresi, Çanakkale.

*Sığrı, Ünsal; Başar, Ufuk (2015), “Etik Liderliğin İyileştirici Etkisi Üzerine Görgül Bir Araştırma”, 23. Ulusal Yönetim ve Organizasyon Kongresi, Muğla.

Valle, Matthew; Perrewé, Pamela L. (2000), "Do Politics Perceptions Relate to Political Behaviors?" Human Relations, Vol. 53, No. 3: 359-386.

Vigoda, Eran, (2000), “Organizational Politics, Job Attitudes and Work Outcomes: Exploration and Implications for the Public Sector", Journal of Vocational Behavior, Vol. 57, No. 3: 336-347.

Witt, L. Alan; Andrews, Martha C.; Kacmar, K. Michele (2000), "The Role of Participation in Decision-Making in the Organizational Politics-Job Satisfaction Relationship", Human Relations, Vol. 53, No. 3: 341-358.

Witt, L.A. (1998), "Enhancing Organizational Goal Congruence: A Solution to Organizational Politics, Journal of Applied Psychology, Vol. 83, No. 4: 666-674.

Yüksel, Murad (2013), “Örgütsel Politika, Hofstede'in Örgüt Kültürü Boyutları, İş Tutumları ve İş Çıktıları illişkisi”, Yayınlanmış Doktora Tezi, Balıkesir Üniversitesi Sosyal Bilimler Enstitüsü, Balıkesir.

*Yüksel, Murad; Bolat, Tamer (2016), “Örgütsel Politika, Hofstede'in Örgüt Kültürü Boyutları, İş Tutumları ve İş Çıktıları ilişkisi”, Eskişehir Osmangazi Üniversitesi iiBF Dergisi, C. 11, S. 3: 173-204.

Zhou, Jing; Ferris, Gerald R. (1995), "The Dimensions and Consequences of Organizational Politics Perceptions: A Confirmatory Analysis", Journal of Applied Social Psychology, Vol. 25, No. 19: 1747-1764. 


\section{Extended Summary}

\section{A Meta-Analysis of the Outcomes of Perceived Organizational Politics in the Context of Turkish Organizational Behavior Literature}

This study makes a systematic analysis of the studies on perceived organizational politics (POPs) in Turkish organizational behavior literature. Specifically, this study seeks to answer the following questions: 1) In the context of research samples from Turkey, what is the set of outcomes most frequently associated with POPs? 2) What is the direction and strength of the correlations between POPS and variables in question? 3) What are the theoretical and practical implications of those associations for the relevant literature? In an attempt to address these questions, and to identify the outcomes of POPs as well as to explore the direction and strength of variable-level correlations, this study uses a meta-analytical approach. To that end, we searched for papers and articles including the keywords "perceived organizational politics", "organizational politics", "perceptions of politics", and "POPs" in the National Academic Network and Information Center, The Council of Higher Education Thesis Center, Academic Search Complete, Business Source Complete, Emerald Insight, ERIC, DOAJ, IEEE XploreDigital Library, JSTOR, PsycINFO, Sage Journals Online, Science Direct, Springer Link, Taylor and Francis Online Journals, Wiley Online Library, Clarivate Analytics (Web of Science) and the Books of Proceedings of the National Congress on Management and Organization, Business Congress and the Congress on Organizational Behavior.

Meta-analysis is a technique that enables quantitative integration of the extant empirical research on a specific topic by providing a systematic and comprehensive examination of a research question. No individual study is robust enough to fully address a research question which makes meta-analysis a prominent technique in both theorybuilding and empirical pursuits. Based on the metanalytic techniques proposed by Hunter and Schmidt, we used random effects model to conduct six different meta-analyses to investigate the outcomes of POPs. To be included in the current meta-analyses, all studies had to a) be empirical, b) investigate the relationship between POPS and some other variables, c) involve an assumption of directionality between the variables in question, d) report correlation coefficients and sample sizes, and e)involve data collected in Turkey. The in-depth searches through aforementioned databases from January to October 2018 resulted in 52 studies, based on the above criteria. However, some studies had to be further eliminated as they provided less than adequate data for meta-analysis such as duplicate data, less than three different studies per variable or studies investigating topics very similar to perceived organizational politics (i.e. political skill or actual political behavior). Consequently, we conducted six different meta-analyses based on data from 18 different studies involving $33(\mathrm{~N}=12492)$ unique data sets. The data spanned twenty-one years from 1997 to 2018. Using Comprehensive Meta-Analysis software, we conducted meta-analyses between POPs and intention to leave $(k=9)$, POPs and job satisfaction $(k=9)$, POPs and identification $(k=4)$, POPs and negligence $(k=4)$, POPs and burnout $(k=4)$, and POPs and commitment $(k=3)$.

Overall, the results indicate that all outcomes variables examined exhibit a statistically significant relationship with perceptions of organizational politics. According to our findings, perceived organizational politics is positively correlated with negligence, intention to leave, and burnout at small-to-moderate effect sizes, and is negatively correlated with identification, job satisfaction and commitment at a moderate level.

Perceived organizational politics has generally been associated with counterproductive organizational behavior and research has usually regarded it as a dark aspect of organizational context. The Revised Model of Organizational Politics Perceptions offered by Ferris and colleagues continues to be the most comprehensive model of POPs with antecedents, moderators and outcomes. In line with the theoretical underpinnings offered in this model, the current study found that the most frequently investigated outcomes of POPs in the context of Turkish samples are job satisfaction and intention to leave. The strongest association is with commitment and there is a negative correlation. The weakest association is with negligence, which is not an integral part of Ferris and colleagues' Revised Model and there is a positive correlation.

The significant correlations between POPs and intention to leave (+) and POPs and job satisfaction (-) are in line with Ferris and colleagues' model as well as with past studies on both national and international levels. In the context of Turkish samples, the correlations are neither too high nor too low although these two variables are among the prominent variables that are purported to be highly influenced by POPs. The relationships between identification and POPs (-), and negligence and POPs (+) are not found in Ferris and colleagues' model, which renders studies investigating these associations somehow divergent from the original theoretical model. However, the extant literature supports the negative influence of POPs on individuals' willingness to participate and involve in as well as to identify with their organization's goals/well-being, and the positive influence on demotivation, dissatisfaction with the organization and subsequent feelings of retaliation in the form of i.e. negligence. The relationship between burnout and POPs (+) is yet another aspect of organizational life that is not directly included in Ferris and colleagues' model. Studies from Turkey have made significant contributions to the theory by revealing the negative connections between the two at least on the national level. However, the negative association between burnout and POPs is not 


\section{Eskişehir Osmangazi Üniversitesi IïBF Dergisi}

very high. Future researchers should be wary of the other variables that contribute to negative employee outcomes in addition to POPs in accounting for counterproductive employee behavior. In other words, samples from Turkey seem to be somehow tolerant of POPs which does not immediately translate into strong counterproductive work behavior or reflective attitudes. Last but not the least, the association between commitment and POPs is a significant part of Ferris and colleagues' model and the national research seems to be attentive to these links. However, the multifactorial structure of commitment seems to be overlooked as there is not enough data to conduct factor-level meta-analysis of the connections between POPs and three dimensions of commitment (normative, affective and continuance). In line with the existing theory, the current meta-analysis revealed significantly negative and moderate levels of correlation between POPs and overall commitment.

All meta-analyses conducted in this study revealed results that "go by the book" as there are no unexpected outcomes. None of the outcome variables investigated herewith is highly correlated with POPs. The most frequently deployed measurement tool for POPs seems to be Hochwarter's (2003) 6-item and single-factorial scale adapted into Turkish by Akdoğan and Demirtaş (2014). This finding is contrary to international context where the primary measurement instrument seems to be Kacmar and Carlson's (1997) 12-item scale. The lack of moderator tests emerges as one of the most significant shortcomings of the current research as the existing literature does not offer adequate data for detailed analyses of contextual variables such as age, ethnicity, cultural differences or sector. The current study is far from offering a nomological network of POPs in the national context, rather we seek to make a modest contribution by quantitatively summarizing the current outlook of the POPs literature in the limited context of samples from Turkey. Finally, this study is not exempt from the file-drawer problem and the possibility of not including all studies that comply with our meta-analysis criteria despite all our efforts for impartiality and comprehensiveness. 